\title{
Oral and intravenous bretylium disposition
}

\begin{abstract}
To compare the oral and intravenous disposition of bretylium tosylate in man, 10 normal male subjects were randomly assigned single doses of $5 \mathrm{mg} / \mathrm{kg}$ bretylium tosylate either orally or intravenously and crossed over 2 wk later to the opposite route (20 studies). Each experiment included sampling for drug in serum and urine over $48 \mathrm{hr}$. Bretylium tosylate was assayed by gas chromatography. Kinetic analysis provided the following mean [coefficient of variation] results: $100 \mathrm{~F}_{\mathrm{Po}}, 22.6 \%$ [40.2\%]; $\mathrm{Cl}_{r}^{\mathrm{W}}, 300 \mathrm{ml} / \mathrm{min}$ [27.8\%]; $\mathrm{Cl}_{r}^{{ }^{\circ}}, 1,268 \mathrm{mg} / \mathrm{min}[54.8 \%] ; \mathrm{Cl}_{B}^{l \mathrm{l}}$, $299 \mathrm{ml} / \mathrm{min}[31.9 \%] ; f, 101 \%[8.7 \%] ; V_{d s s}, 3.37 \mathrm{l} / \mathrm{kg}[30.5 \%] ; \lambda_{l}, 0.0510[12.8 \%] ; \lambda_{l}^{P_{0},} 0.115$ $[52.7 \%] \mathrm{hr}^{-1}$; elimination half-life $\left(\mathrm{t}^{1 / 2}\right)$ after intravenous bretylium tosylate, $13.6 \mathrm{hr}$, and after oral bretylium tosylate, $6.0 \mathrm{hr}$ (harmonic means). Bretylium tosylate binding to plasma proteins in normal volunteer samples was found to be negligible. The results indicate extensive tissue binding of bretylium tosylate. Oral doses of bretylium tosylate are only partially absorbed. Bretylium tosylate is eliminated entirely by the kidneys as unchanged drug. The greater renal clearance after oral than intravenous bretylium tosylate, and the greater elimination rate constant and shorter oral bretylium tosylate $t^{1 / 2}$ are of interest but no explanation is available.
\end{abstract}

\author{
Jeffrey L. Anderson, M.D., Eugene Patterson, B.S., John G. Wagner, Ph.D., \\ James R. Stewart, M.D., Harriet L. Behm, B.S., and \\ Benedict R. Lucchesi, Ph.D., M.D. Ann Arbor, Mich.
}

The Departments of Internal Medicine and Pharmacology, and the Upjohn Center for Clinical Pharmacology, The University of Michigan Medical School

Bretylium tosylate, a quaternary ammonium compound, exerts marked antifibrillatory effects in animals. ${ }^{2}, 3$ Clinical experience has suggested similar effects in man. ${ }^{4}, 6,15,24$ The drug was released for general use in 1978 for life-threatening ventricular arrhythmias that failed to respond to conventional therapy. ${ }^{10,} 16$ Oral use of the drug is currently investigational. Early clinical experience suggests more wide-

Supported in part by Grant SM01-RR-42 from the Division of Research Resources, National Institutes of Health, by a Career Development Grant from the Upjohn Company, Kalamazoo, Mich., and by a grant from Amar-Stone Laboratories, Inc., McGraw Park, Ill.

Received for publication Jan. 21, 1980.

Accepted for publication May 14, 1980

Reprint requests to: Jeffrey L. Anderson, M.D., Heart Station, University Hospital, Ann Arbor, MI 48109. spread use of bretylium in both short- and longterm settings. ${ }^{16}$

Bretylium effects a biphasic cardiovascular response. ${ }^{9,12,20}$ Local norepinephrine release from adrenergic nerve endings causes an initial rise in blood pressure and a positive inotropic effect on the heart after short-term dosing, which is followed by a fall in blood pressure and relative bradycardia, the result of adrenergic neuronal blockade. The major electrophysiologic effect of bretylium is prolongation of the action potential and effective refractory period of specialized tissues of the heart. ${ }^{7}$. 11 Bretylium is the prototype of a separate, unique class of antiarrhythmic drugs. ${ }^{19}$

Bretylium kinetics in man is poorly understood because of difficulty in developing a 
Table I. Coefficients of variation $[\mathrm{CV}(\%)] *$ obtained from duplicate assays

\begin{tabular}{c|c|c|c|c}
\hline Variable & Range & $n$ & Mean & CV $(\%)$ \\
\hline Serum concentration $(\mathrm{ng} / \mathrm{ml})$ & $1,500-2,500$ & 21 & 1,861 & 4.6 \\
& $1,000-1,499$ & 29 & 1,231 & 4.2 \\
Amount excreted in urine $(\mu \mathrm{g} / \mathrm{ml})$ & $500-999$ & 47 & 756 & 4.5 \\
& $<499$ & 63 & 206 & 6.0 \\
& $>40$ & 17 & 52.8 & 6.0 \\
\hline
\end{tabular}

${ }^{*} \mathrm{CV}(\%)=\frac{\mathrm{SD}}{\text { Mean }} \times 100$, where $\mathrm{SD}=\sqrt{\frac{\Sigma \mathrm{d}^{2}}{2 \mathrm{n}}}, \mathrm{d}$ is the difference between duplicate assays, $\mathrm{n}=$ number of samples, and $2 \mathrm{n}=$ number of assays.

Definitions of kinetic parameters

$100 \mathrm{~F}_{\mathrm{I},}$ : Percent of dose reaching circulation unchanged after oral administration

f: Fraction of drug reaching circulation that is ultimately excreted unchanged in the urine

$\mathrm{Cl}_{\mathrm{B}}^{\mathrm{r}}$ : Total body clearance of drug after intravenous administration

$\mathrm{Cl}_{r}^{\mathrm{Ir}}$ : Renal clearance of drug after intravenous administration

$\mathrm{Cl}_{\mathrm{r}}^{\mathrm{Po}}$ : Renal clearance of drug following oral administration

$\mathrm{V}_{\mathrm{dss}}$ : Steady-state volume of distribution

$V_{d}$ area: Volume of distribution area

$\lambda_{l}^{\mathrm{I}}$ : Apparent elimination rate constant after intravenous administration

$\lambda_{1}^{\mathrm{P} O} \mathrm{O}$ : Apparent elimination rate constant after oral administration

$(\mathrm{AUC})_{\mathrm{I}}$ : Area under serum concentrationtime curve from zero to infinite time after single intravenous infusion

$(\mathrm{AUC})_{\mathrm{P}_{0}}$ : Area under serum concentrationtime curve from zero to infinite time after single oral dose

reliable assay of serum drug concentrations. ${ }^{13,14,17,23}$ The recent development of a sensitive and reliable gas chromatographic assay in our laboratory has enabled us to evaluate bretylium kinetics in man. ${ }^{22}$ The objectives of our study were to determine bretylium kinetics in normal subjects in serum and urine after single intravenous doses, and to compare bretylium disposition in the same subjects after single oral doses.

\section{Methods}

Single doses of bretylium tosylate were given both intravenously and orally in a random sequence separated by a 2 -wk interval to 10 healthy men, aged 20 to $47 \mathrm{yr}(\overline{\mathrm{x}}, 27.7 \pm 9.2$; median, $25 \mathrm{yr}$ ). Subjects were in normal health as ascertained by history and physical examination, and weighed between 65 and $85 \mathrm{~kg}$ $(\overline{\mathrm{x}} \pm \mathrm{SD}=68.3 \pm 7.3 \mathrm{~kg})$, which was within $10 \%$ of normal weight for height and age. Subjects were excluded if they had received any medications within the previous 2-wk period. Alcoholism and drug abuse, resting hypotension (less than $90 \mathrm{~mm} \mathrm{Hg}$ systolic blood pressure) or bradycardia (less than 50 beats/min), and known idiosyncrasy towards bretylium or other quaternary ammonium compounds were further exclusion criteria. The approved intravenous formulation of bretylium tosylate (ArnarStone) was used for all intravenous and oral studies.

Experimental protocol. After initial screening, and an overnight fast beginning at 10 P.M., subjects were admitted to the Clinical Research Center of the University of Michigan. Detailed history and physical examination as well as electrocardiogram were obtained.

A heparin lock was inserted in one arm for drawing blood samples. In patients receiving the drug intravenously, a peripheral line was started in the opposite arm and kept open with a dextrose infusion. After initial vital signs and blood samples were obtained, a total of $5 \mathrm{mg} / \mathrm{kg}$ of bretylium tosylate was delivered at a constant rate over $30 \mathrm{~min}$ by a calibrated Harvard infusion pump. The drug was administered in $50 \mathrm{ml}$ of $5 \%$ dextrose. Blood pressure and heart rate were measured every $5 \mathrm{~min}$ for $30 \mathrm{~min}$, then at $1 / 2$ - to 1 -hr intervals for $6 \mathrm{hr}$ and again at 8 , 12,16 , and $24 \mathrm{hr}$. Constant electrocardiographic monitoring was performed for the first $12 \mathrm{hr}$. Blood was drawn just before drug infu- 
Table II. Kinetic parameters of bretylium tosylate

\begin{tabular}{|c|c|c|c|c|c|c|c|}
\hline \multirow[b]{2}{*}{ Subject } & \multirow{2}{*}{$\begin{array}{c}100 F_{P o} \\
(\%)\end{array}$} & \multirow[b]{2}{*}{$f$} & \multirow{2}{*}{$\begin{array}{c}\mathrm{Cl}_{B}^{l \mathrm{~V}} \\
(\mathrm{ml} / \mathrm{min}) \\
\end{array}$} & \multirow{2}{*}{$\begin{array}{c}C l l_{r}^{\mathrm{V}} \\
(\mathrm{ml} / \mathrm{min}) \\
\end{array}$} & \multirow{2}{*}{$\begin{array}{c}\mathrm{Cl}_{r}^{P_{0}} \\
(\mathrm{ml} / \mathrm{min}) \\
\end{array}$} & \multicolumn{2}{|c|}{$V_{d s s}$} \\
\hline & & & & & & 1 & $1 / k g$ \\
\hline 1 & 32.1 & 0.98 & 263 & 257 & 997 & 180 & 2.77 \\
\hline 2 & 12.5 & 0.88 & 475 & 417 & 610 & 314 & 4.52 \\
\hline 3 & 27.3 & 1.03 & 362 & 372 & 1,148 & 255 & 3.90 \\
\hline 4 & 11.6 & 1.09 & 232 & 253 & 1,232 & 161 & 2.50 \\
\hline 5 & 22.4 & 1.05 & 233 & 245 & 1,283 & 178 & 2.58 \\
\hline 6 & 36.6 & 1.01 & 222 & 224 & 1,269 & 202 & 2.31 \\
\hline 7 & 30.4 & 0.91 & 348 & 315 & 2,642 & 257 & 3.64 \\
\hline 8 & 24.6 & 1.02 & 160 & 163 & 2,292 & 142 & 2.21 \\
\hline 9 & 12.7 & 0.98 & 397 & 390 & 599 & 312 & 5.11 \\
\hline 10 & 15.6 & 1.19 & 302 & 360 & 606 & 265 & 4.15 \\
\hline Mean & 22.6 & 1.01 & 299 & 300 & 1,268 & 227 & 3.37 \\
\hline $\mathrm{CV}(\%)^{*}$ & 40.2 & 8.7 & 31.9 & 27.8 & 54.8 & 27.4 & 30.5 \\
\hline
\end{tabular}

*See footnote to Table I for explanation of CV (\%).

sion and at $0,6,15,30$, and $45 \mathrm{~min}$, and $1,1.5$, $2,3,4,6,8,12,16,24$, and $48 \mathrm{hr}$, and at 30 min after the end of infusion. Seven milliliters of blood were obtained on each occasion in uncoated tubes. Serum, separated from clot by centrifugation, was frozen until assayed.

Patients receiving oral doses took $5 \mathrm{mg} / \mathrm{kg}$ bretylium tosylate solution mixed in a glass of orange juice at 0 time. Initial blood sampling and vital signs were checked at $30 \mathrm{~min}, 1 \mathrm{hr}$, and thereafter as for the intravenous protocol. Subjects receiving oral doses on the first admission received intravenous bretylium 2 wk later, and those receiving intravenous drug on the first admission received the oral dose on the second admission.

For each experiment, all urine was collected for $48 \mathrm{hr}$ and fractionated at $6,12,24$, and 48 hr. Two glasses of water $(480 \mathrm{ml})$ were given $1 / 2$ $\mathrm{hr}$ before drug. Two additional liters of oral fluid were encouraged within the first 24-hr period. During drug infusion and for the first $12 \mathrm{hr}$ thereafter, subjects were kept supine in bed. For the subsequent $12 \mathrm{hr}$, they remained primarily in bed, but were allowed to stretch and use the bathroom if there was no postural hypotension. Patients were discharged ambulatory at $24 \mathrm{hr}$, to return at $48 \mathrm{hr}$ for follow-up blood and urine sampling.

Twelve-lead electrocardiograms were obtained prior to drug and at the end of $24 \mathrm{hr}$ before discharge. The following laboratory tests were obtained before drug infusion and 24 hr before discharge: hemoglobin, hematocrit, white blood count, platelet estimate, electrolytes, sugar, and urea nitrogen, creatinine, calcium, uric acid, total protein, albumin, alkaline phosphatase, total bilirubin, aspartate aminotransferase, urine creatinine concentration, and urinalysis.

Plasma protein binding. To assess bretylium plasma protein binding, ${ }^{14} \mathrm{C}$-bretylium tosylate was added to samples of human plasma at $30,3,0.3$, and $0.03 \mu \mathrm{g} / \mathrm{ml}$. Triplicate samples were analyzed at each concentration for fraction of free drug and of bound drug.

Bretylium assay. Bretylium was assayed by gas chromatography using the method of Patterson et al. ${ }^{22}$

Statistical methods. Group means of variables measured before and after drug are given together with standard deviations (SD) as $\bar{x} \pm$ $\mathrm{SD}$. Means followed by coefficients of variation are given as mean [CV\%]. Differences in means at two times (i.e., before and after drug) were analyzed for significance using Student's paired $t$ test. Differences in the means of variables from two groups (i.e., oral and intravenous drug) at the same time point were compared by the unpaired Student's t test. A probability less than or equal to 0.05 was taken as significant. Kinetic parameters were calculated as noted in the Appendix.

\section{Results}

Clinical responses to drug administration. Intravenous bretylium was followed by expected cardiovascular effects. ${ }^{12}$ Infusion was 


\begin{tabular}{c|c|c|l}
\hline \multicolumn{2}{c|}{$V_{d}$ area } & \multirow{2}{*}{$\begin{array}{c}\lambda_{l} \\
\left(h r^{-1}\right)\end{array}$} & $\begin{array}{c}\lambda_{l} \\
\left(h r^{-1}\right)\end{array}$ \\
\hline \multirow{2}{*nnn}{247} & $1 / k g$ & 0.0638 & 0.0757 \\
540 & 3.80 & 0.0528 & 0.228 \\
474 & 7.77 & 0.0458 & 0.0691 \\
276 & 7.25 & 0.0503 & 0.155 \\
275 & 4.29 & 0.0509 & 0.107 \\
275 & 3.97 & 0.0483 & 0.0367 \\
492 & 3.15 & 0.0425 & 0.0908 \\
167 & 6.96 & 0.0575 & 0.199 \\
436 & 2.59 & 0.0546 & 0.0774 \\
413 & 7.15 & 0.0438 & 0.115 \\
360 & 6.47 & 0.0510 & 0.115 \\
35.1 & 36.34 & 12.8 & 52.7 \\
\hline
\end{tabular}

associated with symptoms of catecholamine release (anxiety, excitement, or flushing) in six of ten subjects. Blood pressure (systolic/diastolic) rose from $115.8 \pm 10.1 / 77.6 \pm 9.5$ to $144.8 \pm 22.3 / 97.4 \pm 14.4 \mathrm{~mm} \mathrm{Hg}(\mathrm{p}<0.01)$ at end of infusion. Heart rate rose from $62.4 \pm 7.6$ to $67.7 \pm 8.7$ beats $/ \mathrm{min}$. Blood pressure then declined at $30 \mathrm{~min}$ and returned to baseline by $1 \mathrm{hr}$ after infusion. Postural symptoms such as dizziness were reported in four subjects during the first several hours after infusion, and in five a fall in systolic pressure to less than $100 \mathrm{~mm} \mathrm{Hg}$ occurred at $12 \mathrm{hr}$ on standing. Nasal congestion was reported in seven, and was usually noted within 1 to $2 \mathrm{hr}$ of infusion and resolved gradually over several hours. Transient headache and nausea were each reported in two patients towards the end of infusion.

After oral dose, blood pressure changes, signs of catecholamine release, and other side effects were small or absent. Systolic blood pressure and heart rate increased at $30 \mathrm{~min}$ only: $104.0 \pm 10.2$ to $119.0 \pm 9.4 \mathrm{~mm} \mathrm{Hg}$ and $62.4 \pm 7.1$ to $67.2 \pm 5.6$ beats $/ \mathrm{min}(\mathrm{p}<0.05$ for each change).

Reproducibility of drug assay. Coefficients of variation (CVs) obtained from duplicate assays for bretylium in serum and urine are presented in Table I. There was excellent reproducibility in all concentration ranges; $\mathrm{CVs}$ were $4.2 \%$ to $6.0 \%$ except when urinary concentration was under $14 \mu \mathrm{g} / \mathrm{ml}$, in which case $\mathrm{CV}$ was $10.1 \%$.

Kinetic parameters for bretylium tosylate.

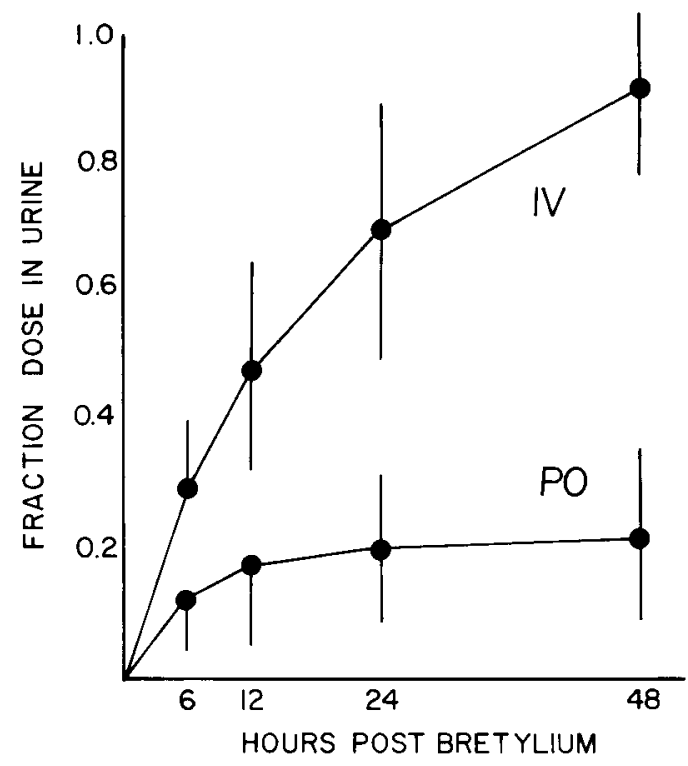

Fig. 1. Urinary excretion-time curve for bretylium after intravenous (upper curve) and oral dosing (lower curve). Values are plotted as $\bar{x} \pm$ SD of fraction dose in urine at indicated times.

Individual and mean kinetic parameters, along with respective CVs, are given in Table II for the 10 subjects. The mean renal clearance for bretylium after oral doses $\left(\mathrm{Cl}_{r}^{\mathrm{P}^{\circ}}=1,268 \mathrm{ml} /\right.$ $\mathrm{min})$ was greater than the mean renal clearance after intravenous doses $\left(\mathrm{Cl}_{\mathrm{r}}^{\mathrm{IV}}=300 \mathrm{ml} / \mathrm{min}\right)$ by paired t test $(p<0.01)$. The ratio of the means of $\mathrm{Cl}_{\mathrm{r}}^{\mathrm{Po}} / \mathrm{Cl}_{\mathrm{r}}^{\mathrm{IV}}$ equaled 4.2.

The differences in disposition of oral and intravenous doses were also evident in the apparent elimination rate constants. The mean elimination rate constant after oral doses, $\lambda_{l}^{P^{0}}=$ $0.115 \mathrm{hr}^{-1}$, was greater $(\mathrm{p}<0.01$, paired $\mathrm{t}$ test $)$ than after intravenous doses, namely $\lambda_{l}^{I V}=$ $0.0510 \mathrm{hr}^{-1}$. The ratio of the means of $\lambda_{1}^{\mathrm{Po} / I_{1}^{\mathrm{V}}}$ equaled 2.3 .

The change in renal clearance of bretylium with change in route of administration necessitated the use of a special equation (Appendix, equation 6) to estimate bioavailability (efficiency of absorption) after oral doses, symbolized by $100 \mathrm{~F}_{\mathrm{P} 0}$. Based on this calculation, an average of only $22.6 \%$ [40.2\%] of the oral dose (range $11.6 \%$ to $32.1 \%$ ) of bretylium tosylate was absorbed.

Although urinary excretion of bretylium was not quite asymptotic at $48 \mathrm{hr}$ when urine sampling ceased (Fig. 1, Table III), the ratio 
Table III. Urinary excretion of bretylium

\begin{tabular}{|c|c|c|c|c|c|c|c|c|c|c|}
\hline \multirow[b]{3}{*}{ Subject } & \multicolumn{10}{|c|}{ Amounts of bretylium base* excreted in urine $(\mathrm{mg})$} \\
\hline & \multicolumn{5}{|c|}{ Oral $(h r)$} & \multicolumn{5}{|c|}{ Intravenous (hr) } \\
\hline & $0-6$ & $6-12$ & $12-24$ & $24-48$ & $0-48$ & $0-6$ & $6-12$ & $12-24$ & $24-48$ & $0-48$ \\
\hline 1 & 13.2 & 20.5 & 11.8 & 7.5 & 53.0 & 38.0 & 27.0 & 41.0 & 54.0 & 160 \\
\hline 2 & 15.1 & 2.5 & 1.2 & 0.9 & 19.7 & 46.0 & 25.8 & 38.7 & 41.8 & 152 \\
\hline 3 & 22.0 & 12.3 & 2.2 & 9.7 & 46.2 & 52.8 & 33.4 & 39.4 & 42.8 & 168 \\
\hline 4 & 6.0 & 7.7 & 3.9 & 2.5 & 20.1 & 44.5 & 37.1 & 36.8 & 56.9 & 175 \\
\hline 5 & 26.0 & 6.6 & 3.1 & 4.1 & 39.8 & 55.4 & 54.1 & 35.5 & 36.7 & 174 \\
\hline 6 & 63.1 & 1.3 & 4.2 & 3.1 & 71.7 & 88.3 & 55.1 & 55.0 & + & 198 \\
\hline 7 & 20.0 & 11.9 & 9.4 & 12.6 & 53.9 & 29.0 & 22.7 & 38.6 & 44.1 & 134 \\
\hline 8 & 29.3 & 5.1 & 5.4 & 2.7 & 42.5 & 55.9 & 30.0 & 32.0 & 34.0 & 152 \\
\hline 9 & 12.2 & 1.27 & 1.25 & 4.7 & 19.4 & 38.1 & 16.5 & 46.3 & 33.7 & 135 \\
\hline 10 & 15.7 & 7.0 & 4.6 & 1.1 & 28.4 & 72.2 & 39.5 & 17.5 & 30.0 & 159 \\
\hline Mean & 22.3 & 7.6 & 4.7 & 4.9 & 39.5 & 52.0 & 33.3 & 38.1 & 41.6 & 161 \\
\hline $\mathrm{CV}(\%) \ddagger$ & 71.5 & 78.0 & 73.0 & 79.0 & 44.5 & 33.7 & 34.6 & 25.3 & 22.1 & 12 \\
\hline
\end{tabular}

*Bretylium base equals $0.52 \%$ of bretylium tosylate by weight.

†No sample.

$\ddagger$ See footnote to Table I for explanation of CV (\%).

Table IV. Mean serum concentrations and coefficients of variation $(\mathrm{CV})$

\begin{tabular}{|c|c|c|c|c|}
\hline \multirow[b]{2}{*}{$\begin{array}{c}\text { Time* } \\
(h r)\end{array}$} & \multicolumn{2}{|c|}{ Oral } & \multicolumn{2}{|c|}{ Intravenous } \\
\hline & $\begin{array}{c}\text { Mean } \\
(n g / m l)\end{array}$ & $\begin{array}{c}C V \\
(\%) \dagger\end{array}$ & $\begin{array}{c}\text { Mean } \\
(n g / m l)\end{array}$ & $\begin{array}{c}C V \\
(\%) \dagger\end{array}$ \\
\hline 0.1 & $\dagger$ & - & 1,567 & 24.5 \\
\hline 0.25 & $\ddagger$ & - & 1,375 & 24.6 \\
\hline 0.5 & 17 & 84 & 1,231 & 26.2 \\
\hline 0.75 & 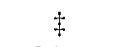 & - & 1,109 & 25.8 \\
\hline 1 & 34 & 118 & 955 & 25.0 \\
\hline 1.5 & 39 & 84 & 883 & 26.5 \\
\hline 2 & 45 & 67 & 778 & 27.2 \\
\hline 3 & 48 & 42 & 597 & 45.9 \\
\hline 4 & 46 & 64 & 548 & 37.5 \\
\hline 6 & 34 & 52 & 431 & 39.7 \\
\hline 8 & 28 & 83 & 343 & 45.7 \\
\hline 12 & 18 & 51 & 237 & 48.6 \\
\hline 16 & 12 & 54 & 162 & 54.1 \\
\hline 24 & 5.4 & 77 & 96 & 53 \\
\hline 48 & 0.9 & - & 28 & 49 \\
\hline
\end{tabular}

*Time after oral dose or time measured from the end of the infusion for intravenous doses.

tSee footnote to Table I for explanation of CV (\%).

‡Samples not taken.

$\mathrm{f}=\mathrm{Cl}_{\mathrm{r}}^{\mathrm{IV}} / \mathrm{Cl}_{\mathrm{B}}^{\mathrm{lV}}$ indicated that if urine had been collected long enough, an average of $101 \%$ [8.7\%], the entire dose (range $88 \%$ to $119 \%$ ), would have been excreted (Table II). This strongly suggests that most, if not all, of the subjects did not metabolize bretylium tosylate.
The very large estimated volumes of distribution $\left(\mathrm{V}_{\mathrm{dss}}, \mathrm{V}_{\mathrm{d} \text { area }}\right.$ ) of 3.4 and $5.3 \mathrm{l} / \mathrm{kg}$ (Table II) suggest that bretylium is highly bound to tissue.

Creatinine clearance $(\mathrm{CrCl})$ after intravenous doses averaged $112 \pm 20 \mathrm{ml} / \mathrm{min}$ during day 1 (inpatient), and $103 \pm 19 \mathrm{ml} / \mathrm{min}$ during day 2 (outpatient). After oral doses, $\mathrm{CrCl}$ was $120 \pm$ $27 \mathrm{ml} / \mathrm{min}$ during day 1 (inpatient) and $114 \pm$ $19 \mathrm{ml} / \mathrm{min}$ during day 2 (outpatient). Differences in $\mathrm{CrCl}$ by route of administration were not significant. The ratio of clearances of bretylium to creatinine were: $\mathrm{Cl}_{\mathrm{r}}^{\mathrm{IV}} / \mathrm{CrCl}^{\mathrm{IV}}=$ $2.75 \pm 0.83$, and $\mathrm{Cl}_{\mathrm{r}}^{\mathrm{Po}} / \mathrm{CrCl}^{\mathrm{Po}}=11.00 \pm$ 6.30. The ratios varied widely, especially after oral doses, and there was no correlation between individual clearances of the two substances.

Plasma protein binding of bretylium tosylate. In contrast to its marked tissue-binding properties, bretylium did not bind at all to plasma proteins. Plasma binding was tested in samples from a normal human and found to be negligible at four plasma drug concentrations: $30,3,0.3$, and $0.03 \mu \mathrm{g} / \mathrm{ml}$. The fraction of free drug determined at the three higher plasma concentrations averaged $99 \%$ [3.9\%] free. At the lowest drug concentration, $0.03 \mu \mathrm{g} / \mathrm{ml}$, binding to plasma protein was also negligible, but with a larger coefficient of variation attributed to the 


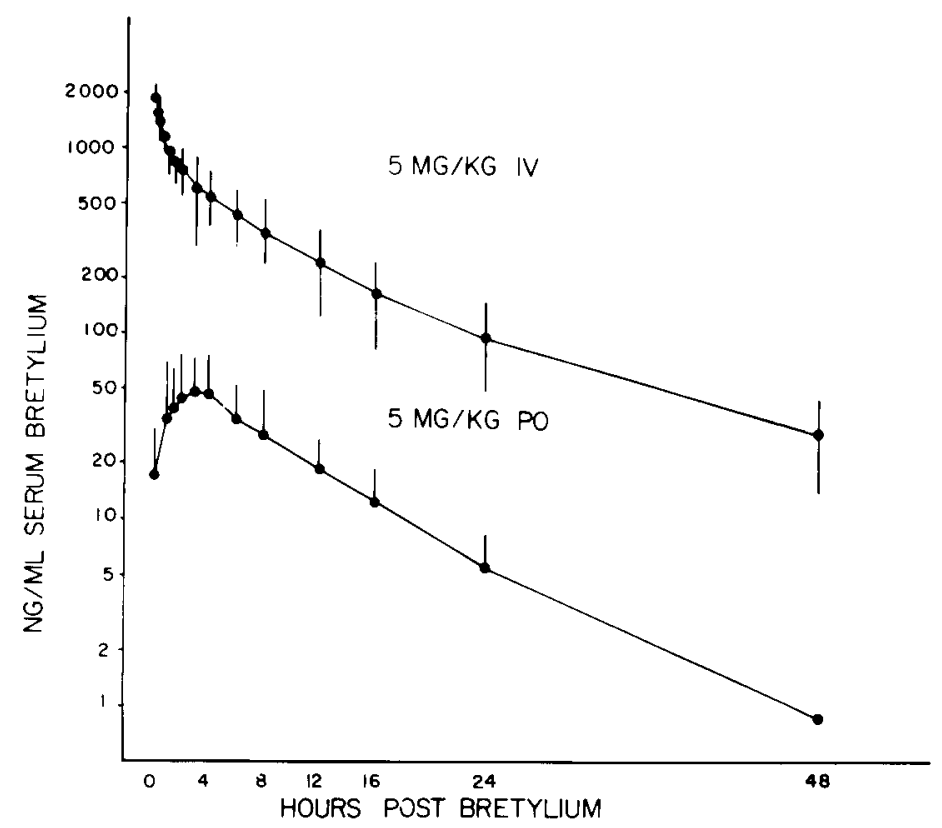

Fig. 2. Mean serum concentration-time curves for bretylium after intravenous (upper curve) and oral dosing (lower curve). Means are plotted together with SD.

extremely low radioactive count rate at this low drug concentration.

Serum elimination curve. Mean serum concentrations after oral and intravenous bretylium in 10 patients ( 20 experiments) are given for various times between 0.1 and $48 \mathrm{hr}$ in Table IV and Fig. 2. Representative data for an individual patient are presented in Fig. 3 for both intravenous and oral administration. Despite rapid decline in serum bretylium concentration $\left(C_{\mathrm{s}}\right)$ in the first $3 \mathrm{hr}$ after intravenous doses, CVs were remarkably small (ca $25 \%$ ) but there were extremely large CVs (67\% to $118 \%$ ) during the first $2 \mathrm{hr}$ after oral doses. Later time points also display greater $\mathrm{CVs}$ for oral than for intravenous doses. Rapid, early fluctuations in serum bretylium concentrations were not uncommon after oral doses (Fig. 3) but were not present after intravenous doses. These variations greatly exceeded those attributable to the assay, and suggest differences in initial handling of oral drug. Intestinal secretion of drug, uneven absorption, or other explanations may apply, but these mechanisms were not addressed in this study.

Urinary excretion of bretylium. Fractional and total bretylium base excreted in the urine (mg) within $48 \mathrm{hr}$ are given in Table III for individual subjects receiving oral and intravenous doses. The three-to fourfold difference in mean CV (44.5\% and 12\%) in excretion after oral than after intravenous administration is noteworthy. Assuming negligible bretylium metabolism, this implies substantial variation in oral absorption. The ratio of urinary recovery after oral and intravenous doses (39.5/161 = 0.245 ) is internally consistent with calculated mean oral fractional absorption $\left(\mathrm{F}_{\mathrm{P}_{0}}=0.226\right.$, Table II).

Peak serum concentrations of drug. The peak serum bretylium concentration and time of peak after oral as well as intravenous doses are given by individual subject in Table V. Of note is the wide range of time to peak after oral doses, ranging from 1 to $8.5 \mathrm{hr}$, with a mean of $3.05[72 \%]$ hr. Peak concentration averaged 76 $[49 \%] \mathrm{ng} / \mathrm{ml}$. Mean peak concentration of bretylium at the end of $0.5 \mathrm{hr}$ intravenous infusion was $1,896[24.7 \%] \mathrm{ng} / \mathrm{ml}, 28$ times that of the peak after oral drug.

Areas under serum concentration-time curves. Table VI compares the areas under individual and group concentration-time curves for 0 to $48 \mathrm{hr}$ with those estimated for the inter- 


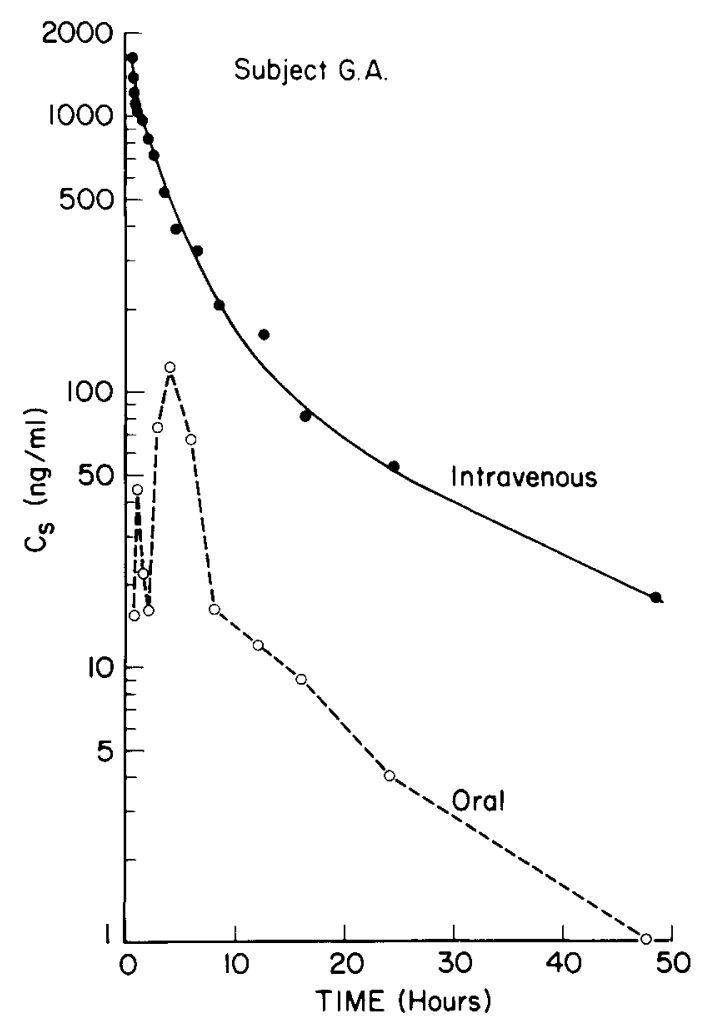

Fig. 3. Serum concentration-time curves in subject 3 (G. A.) after $5 \mathrm{mg} / \mathrm{kg}$ bretylium tosylate intravenously and orally. Ordinate is serum concentration (Cs) bretylium ( $\mathrm{ng} / \mathrm{ml}$ ); abscissa is time (hr).

val 0 -infinity. This ratio, expressed as a percentage $(P)$, indicates virtually total accounting for drug within $48 \mathrm{hr}$ after oral doses (97.0\% [4.6\%]), and 90\% [7.1\%] within $48 \mathrm{hr}$ after intravenous doses.

Determination of elimination rate constants. Serum bretylium concentrations corresponding to times indicated in Table VII were used to estimate the apparent elimination rate constants, $\lambda_{1}^{\mathrm{VV}}$ and $\lambda_{1}^{\mathrm{Po}}$. Semilogarithmic plots of serum concentrations of bretylium were curvilinear up to $24 \mathrm{hr}$ in nine and twenty data sets, up to $16 \mathrm{hr}$ in seven data sets, up to $12 \mathrm{hr}$ in two data sets, up to $8 \mathrm{hr}$ in one data set, and up to 6 $\mathrm{hr}$ in the other data set. Estimation of elimination rate constants and half-lifes ( $\left.t^{1 / 2} \mathrm{~s}\right)$ using these curvilinear regions would give biased results. We used only those data points which appeared to be randomly distributed about a straight line on semilogarithmic graph paper, or the 24- and 48-hr values, to estimate the elimination rate constants. The mean elimination rate constant of $0.115 \mathrm{hr}^{-1}$ after oral administration corresponds to an elimination $t^{1} / 2$ of $6.0 \mathrm{hr}$, while the mean rate constant of $0.0510 \mathrm{hr}^{-1}$ after intravenous dosing corresponds to an elimination $\mathrm{t}^{1 / 2}$ of $13.6 \mathrm{hr}$ (harmonic mean).

Clinical and laboratory responses after bretylium. Biochemical, hematologic, and electrocardiographic testing before and $24 \mathrm{hr}$ after drug showed few changes except for evidence of hemoconcentration after both intravenous and oral dosing. Hemoconcentration was reflected by small increases in total protein, albumin, hemoglobin, hematocrit, and red blood cell concentration. Hemoglobin, for example, rose from $14.7 \pm 1.0$ to $16.3 \pm 1.2 \mathrm{gm}(\mathrm{p}<$ 0.01 ). Urine specific gravity did not change. The only significant biochemical change was a small decrease in chloride concentration $(107.1 \pm 1.6$ to $105.3 \pm 1.5 \mathrm{mEq} / l)(\mathrm{p}=<$ $0.05)$. Creatinine ranged from 0.7 to $1.2 \mathrm{mg} / \mathrm{dl}$ $(\bar{x}, 0.99 \pm 0.13)$ before drug, and urea nitrogen from 11 to $20 \mathrm{mg} / \mathrm{dl}(\overline{\mathrm{x}}, 14.4 \pm 2.5)$. Both were unchanged at $24 \mathrm{hr}$. Postural rather than direct drug effects might be invoked to explain hemoconcentration ${ }^{26}$; all patients were supine, whereas patients receiving drug intravenously had markedly higher serum concentrations of bretylium but no greater degree of hemoconcentration. There were no changes in QRS, Q-T intervals, or heart rate in electrocardiograms taken at $24 \mathrm{hr}$. Mean P-R decreased slightly $(0.158$ to $0.151, p=0.01)$. All patients tolerated the study well. There were no complications except for postural syncope in one subject who, despite orders to the contrary, stood to urinate $4 \mathrm{hr}$ after intravenous bretylium. No injury was sustained.

\section{Discussion}

This study extends previous kinetic information on bretylium. ${ }^{13}, 14,17,23$ Romhildt et al. estimated average serum $t^{1 / 2}$ to be $10 \mathrm{hr}$ after intramuscular injection. ${ }^{23}$ Kuntzman et al. described non-first-order elimination during the first $24 \mathrm{hr}$ after bretylium, with an elimination $\mathrm{t}^{1 / 2}$ of at least 5 to $6 \mathrm{hr} \cdot{ }^{17}$ Holder et al. claimed bretylium facilitated cardioversion from ventricular fibrillation within minutes of adminis- 
Table V. Peak serum concentrations of bretylium and time of peak serum concentrations

\begin{tabular}{c|c|c|c}
\hline \multirow{2}{*}{ Subject } & \multicolumn{2}{|c|}{ Oral } & Intravenous \\
\cline { 2 - 4 } & $\begin{array}{c}\text { Peak concentration } \\
(\mathrm{ng} / \mathrm{ml})\end{array}$ & $\begin{array}{c}\text { Time of peak } \\
(\mathrm{hr})\end{array}$ & $\begin{array}{c}\text { Peak concentration (ng/ml) } \\
\text { at end of O.5-hr infusion }\end{array}$ \\
\hline 1 & 91 & 8.5 & 1,868 \\
2 & 84 & 3 & 1,134 \\
3 & 123 & 4 & 1,602 \\
4 & 96 & 2 & 2,154 \\
5 & 50.2 & 2 & 1,819 \\
6 & 56.2 & 4 & 2,358 \\
7 & 38 & 2 & 2,436 \\
8 & 43 & 1 & 2,144 \\
9 & 38 & 3 & 1,169 \\
10 & 143 & 1 & 2,277 \\
Mean & 76 & 3.05 & 1,896 \\
CV $(\%)^{*}$ & 49 & 72 & 24.7 \\
\hline
\end{tabular}

${ }^{*}$ See footnote to Table I for explanation of $\mathrm{CV}(\%)$.

Table VI. Areas under serum concentration-time curves

\begin{tabular}{c|c|c|c|r|r|c}
\hline & \multicolumn{6}{c}{ AUC $\left(\frac{\mu g}{m l} \times h r\right)$} \\
\cline { 2 - 7 } Subject & \multicolumn{7}{|c}{ Oral } & \multicolumn{3}{c}{ Intravenous } \\
\cline { 2 - 7 } & $0-48 h r$ & $0-x$ & $P^{*}$ & $0-48 h r$ & $0 . \infty$ & $P^{*}$ \\
\hline 1 & 0.886 & 0.903 & 98.1 & 10.395 & 10.724 & 96.9 \\
2 & 0.538 & 0.553 & 97.3 & 6.078 & 6.324 & 96.1 \\
3 & 0.671 & 0.685 & 98.0 & 7.525 & 7.918 & 95.0 \\
4 & 0.272 & 0.279 & 97.5 & 11.520 & 11.987 & 96.1 \\
5 & 0.517 & 0.522 & 99.0 & 11.811 & 12.720 & 92.9 \\
6 & 0.942 & 1.114 & 84.6 & 14.764 & 17.039 & 86.6 \\
7 & 0.340 & 0.344 & 98.8 & 7.098 & 8.833 & 80.4 \\
8 & 0.309 & 0.309 & 100.0 & 15.498 & 17.442 & 88.9 \\
9 & 0.540 & 0.554 & 97.5 & 5.773 & 6.669 & 86.6 \\
10 & 0.781 & 0.784 & 99.6 & 7.353 & 9.155 & 80.3 \\
Mean & 0.580 & 0.605 & 97.0 & 9.782 & 10.88 & 90.0 \\
CV $(\%) \dagger$ & 40.9 & 44.8 & 4.6 & 36.2 & 36.3 & 7.1 \\
\hline
\end{tabular}

*AUC 0-48 hr expressed as a percentage of the estimated AUC $0-\infty$.

t See footnote to Table I for explanation of $\mathrm{CV}(\%)$.

tration. ${ }^{15}$ Romhildt et al. reported the maximal antiarrhythmic effect to be delayed until $6 \mathrm{hr}$, whereas the antihypertensive effect occurred after $1 \mathrm{hr} .{ }^{23}$ Our study of tissue bretylium kinetics in the dog suggested both peak cardiac cumulation and peak antifibrillatory effect to be delayed until 3 to $6 \mathrm{hr} .{ }^{2}$ Serum and myocardial bretylium did not reach pseudoequilibrium until $12 \mathrm{hr}$, after which parallel elimination occurred with $t^{1 / 2}$ of $10.5 \mathrm{hr}$.

In this study we analyzed for the first time both intravenous and oral disposition of bre- tylium in man, and compared the disposition of the two routes for a full $48 \mathrm{hr}$. The curvilinear nature of semilogarithmic plots of serum concentration:time for at least $12 \mathrm{hr}$ in most instances suggests that bretylium elimination does not fit a classic two-compartment open model.

Mean apparent elimination rate constant after oral administration $\left(\lambda_{1}^{P_{0}}=0.115 \mathrm{hr}^{-1}\right)$ was greater than that after intravenous doses $\left(\lambda_{1}^{I^{V}}=\right.$ $0.510 \mathrm{hr}^{-1}$ ). Greater mean renal clearance of bretylium after oral doses than after intravenous doses agrees with the differences in elimination 
Table VII. Corresponding serum bretylium concentrations and times used to estimate the apparent elimination rate constants, $\lambda_{l}^{I V}$ and $\lambda_{l}^{P_{0}}$

\begin{tabular}{|c|c|c|c|c|c|c|c|}
\hline \multirow[b]{2}{*}{ Subject } & \multirow[b]{2}{*}{ Route } & \multicolumn{6}{|c|}{$\begin{array}{c}\text { Time }(h r) \text { after oral } \\
\text { dosing or the end of } \\
\text { infusion }\end{array}$} \\
\hline & & 6 & 8 & 12 & 16 & 24 & 48 \\
\hline 1 & $\begin{array}{l}\text { Intravenous } \\
\text { Oral }\end{array}$ & & & & & $\begin{array}{l}x \\
x\end{array}$ & $\begin{array}{l}x \\
x\end{array}$ \\
\hline 2 & $\begin{array}{l}\text { Intravenous } \\
\text { Oral }\end{array}$ & & & & $\begin{array}{l}x \\
X\end{array}$ & $\begin{array}{l}x \\
x\end{array}$ & $\begin{array}{c}X \\
\text { ND }\end{array}$ \\
\hline 3 & $\begin{array}{l}\text { Intravenous } \\
\text { Oral }\end{array}$ & & $X$ & $X$ & $x$ & $\begin{array}{l}x \\
b\end{array}$ & $\begin{array}{l}x \\
x\end{array}$ \\
\hline 4 & $\begin{array}{l}\text { Intravenous } \\
\text { Oral }\end{array}$ & & & $\begin{array}{l}x \\
x\end{array}$ & $\begin{array}{l}X \\
X\end{array}$ & $\begin{array}{l}\text { ND } \\
\text { ND }\end{array}$ & $\begin{array}{l}\text { ND } \\
\text { ND }\end{array}$ \\
\hline 5 & $\begin{array}{l}\text { Intravenous } \\
\text { Oral }\end{array}$ & & & & $X$ & $\begin{array}{l}x \\
x\end{array}$ & $\begin{array}{l}X \\
\text { ND }\end{array}$ \\
\hline 6 & $\begin{array}{l}\text { Intravenous } \\
\text { Oral }\end{array}$ & & & & & $\begin{array}{l}x \\
x\end{array}$ & $\begin{array}{l}x \\
x\end{array}$ \\
\hline 7 & $\begin{array}{l}\text { Intravenous } \\
\text { Oral }\end{array}$ & & & $x$ & $X$ & $\begin{array}{l}x \\
x\end{array}$ & $\begin{array}{c}X \\
\text { ND }\end{array}$ \\
\hline 8 & $\begin{array}{l}\text { Intravenous } \\
\text { Oral }\end{array}$ & $x$ & $x$ & $x$ & $\begin{array}{l}x \\
x\end{array}$ & $\begin{array}{l}\mathrm{X} \\
*\end{array}$ & $\begin{array}{c}X \\
\text { ND }\end{array}$ \\
\hline 9 & $\begin{array}{l}\text { Intravenous } \\
\text { Oral }\end{array}$ & & & & $X$ & $\begin{array}{l}x \\
x\end{array}$ & $\begin{array}{l}X \\
\text { ND }\end{array}$ \\
\hline 10 & $\begin{array}{l}\text { Intravenous } \\
\text { Oral }\end{array}$ & & & & $\begin{array}{l}x \\
x\end{array}$ & $\begin{array}{l}x \\
x\end{array}$ & $\begin{array}{c}X \\
\text { ND }\end{array}$ \\
\hline
\end{tabular}

$\mathrm{ND}=$ Bretylium not detectable in the sample.

* Concentration detectable but not included in estimation of the rate constant since markedly off trend of other points.

rate and $t 1 / 2$ by route of administration. Renal clearance of bretylium by both routes is much higher than creatinine clearance. Measured renal clearance of bretylium after oral doses $(1,268 \mathrm{ml} / \mathrm{min})$ equals total estimated renal blood flow. Assuming serum and whole blood concentrations to be equal, this suggests that drug is virtually completely cleared from blood during a single passage through the kidney. ${ }^{8}$

The cause of the discrepant elimination after oral and intravenous bretylium is not clear and may relate to both concentration-dependent renal clearance and to route of administration per se. Our protocol with four urinary collection periods did not provide sufficient data to determine the quantitative relationship between urinary excretion rate and serum concentration. These data did provide some evidence of a non- linear relationship between instantaneous urinary excretion rate and the corresponding serum concentrations but in the urinary excretion range where a comparison between oral and intravenous data was feasible, there were additional differences between the two routes. It should be emphasized that clearances as reported are estimated over the entire time interval from zero to infinity after the single doses (see Appendix). Determining the exact relationship between instantaneous urinary excretion rates and serum concentrations thus requires further study.

Experimental evidence suggests an active transport system for quaternary ammonium compounds by the renal tubular epithelium and intestinal mucosa. ${ }^{1}{ }^{25}, 28$ A secretory mechanism that becomes saturable with rising serum concentration has been postulated for these compounds to explain observed dose dependency and time dependency of disposition. Such a mechanism might, in part, explain the relatively slower excretion at the higher concentrations after intravenous doses. Another consideration is that after intravenous bretylium, redistribution of intravascular fluid may occur in response to higher bretylium concentration and result in lower renal plasma flow, but differences in creatinine clearance between intravenous and oral drug were not significant. Such possibilities as irregular temporal absorption of drug from the gastrointestinal tract, intestinal secretion, or enterohepatic recycling of drug to explain variation in the initial serum concentration-time curves after oral drug also need further investigation.

Our results indicate that if serum is collected long enough, virtually the entire dose of intravenously administered drug is excreted. This suggests that most, if not all, subjects do not metabolize bretylium, but excrete it unchanged in urine. This emphasizes the importance of renal excretion in determining drug elimination and should suggest appropriate modification in dosage when giving bretylium to patients with renal insufficiency.

Very large values for volumes of distribution of bretylium indicate it to be highly bound to tissue in man, but not at all to plasma proteins. Previous work in experimental animals indi- 
cates extensive bretylium cumulation in sympathetic ganglia and in their postganglionic nerves, and also in various tissues, particularly heart, liver, spleen, and kidneys ${ }^{8,}{ }^{21}$ but it does not cumulate in the central nervous system. ${ }^{8}$

Limited bretylium absorption after oral dosing is not surprising in view of the low lipid solubility and fixed positive charge of its quaternary structure. ${ }^{25}$ This suggests potential difficulty in the clinical use of an oral formulation. The lower therapeutic range for serum concentration is not known, but much higher oral doses will certainly be needed to match the concentrations after intravenous bretylium. The disposition of these equivalent, much larger oral doses of drug should be investigated separately to evaluate dose-dependent effects in disposition. Because of the variability of absorption, it may also be important to determine serum concentrations in patients taking bretylium by mouth.

\section{References}

1. Acara M, Rennick B: Renal tubular transport of acetylcholine and atropine: Enhancement. J Pharmacol Exp Ther 182:14-26, 1972.

2. Anderson JL, Patterson E, Conlin M, Pitt B, Lucchesi BR: Clinical and laboratory pharmacokinetics of bretylium using a new drug assay. Circulation 60(part II):201, 1979.

3. Bacaner MB: Quantitative comparison of bretylium with other antifibrillatory drugs. Am J Cardiol 21:504-512, 1968.

4. Bacaner MB: Treatment of ventricular fibrillation and other acute arrhythmias with bretylium tosylate. Am J Cardiol 21:530-543, 1963.

5. Benet LZ, Galeazzi RL: Noncompartmental determination of the steady-state volume of distribution. J Pharm Sci 68:1071-1074, 1979.

6. Bemstein JG, Koch-Weser J: Effectiveness of bretylium tosylate against refractory ventricular arrhythmias. Circulation 45: 1024-1034, 1972.

7. Bigger JT Jr, Jaffe CC: The effect of bretylium tosylate on the electrophysiologic properties of ventricular muscle and Purkinje fibers. Am J Cardiol 27:82-92, 1971.

8. Boura ALA, Copp FC, Duncombe WG, Green AF, McCoubrey A: The selective accumulation of bretylium in sympathetic ganglia and their postganglionic nerves. J Pharmacol 15:265, 1960.

9. Boura ALA, Green AF: The actions of bretylium: Adrenergic neurone blocking and other effects. Br J Pharmacol 14:536-548, 1959.

10. Bretylium (Bretylol) for ventricular arrhythmias. Med Lett Drugs Ther 20:105-106, 1978.
11. Cardinal R, Sasyniuk BI: Electrophysiological effects of bretylium tosylate on subendocardial Purkinje fibers from infarcted canine hearts. J Pharmacol Exp Ther 204:159-174, 1978.

12. Chatterjee K, Mandel WJ, Vyden JK, Parmley WW, Forrester JS: Cardiovascular effects of bretylium tosylate in acute myocardial infarction. JAMA 223:757-760, 1973.

13. Dollery CT, Emslie-Smith D, McMichael J: Bretylium tosylate in the treatment of hypertension. Lancet 2:296-299, 1960.

14. Duncombe WG, McCoubrey A: The excretion and stability to metabolism of bretylium. $\mathrm{Br} \mathrm{J}$ Pharmacol 15:260-264, 1960.

15. Holder DA, Sniderman AD, Fraser DG, Fallen E: Experience with bretylium tosylate by a hospital cardiac arrest team. Circulation 55:541544, 1977.

16. Koch-Weser J: Drug therapy, bretylium. N Engl J Med 300:473-477, 1979.

17. Kuntzman R, Tsai I, Chang R, Conney AH: Disposition of bretylium in man and rat. CLIN Pharmacol Ther 5:829-837, 1970.

18. Kwan KC, Till AE: Novel method for bioavailability assessment. J Pharm Sci 62:1494-1497, 1973 .

19. Lucchesi BR: Antiarrhythmic drugs, in Antonaccio $\mathrm{M}$, editor: Cardiovascular pharmacology. New York, 1977, Raven Press.

20. Markis JE, Koch-Weser J: Characteristics and mechanism of inotropic and chronotropic actions of bretylium tosylate. J Pharmacol Exp Ther 178:94-102, 1971.

21. Namm DH, Wang CM, Sayad S, Copp FC, Maxwell RA: Effects of bretylium on rat cardiac muscle: The electrophysiological effects and its uptake and binding in normal and immunosympathectomized rat hearts. J Pharmacol Exp Ther 193:194-207, 1974.

22. Patterson E, Stetson P, Lucchesi BR: Sensitive gas chromatographic assay for the quantitation of bretylium in plasma, urine, and myocardial tissue. J Chromatogr 181:33-39, 1980.

23. Romhildt DW, Bloomfield SS, Lipicky RJ, Welch RM, Fowler NO: Evaluation of bretylium tosylate for the treatment of premature ventricular contractions. Circulation 45:800-807, 1972.

24. Sanna G, Arcidiacono R: Chemical ventricular defibrillation of the human heart with bretylium tosylate. Am J Cardiol 32:982-987, 1973.

25. Turnheim K, Lauterbach FO: Absorption and secretion of monoquaternary ammonium compounds by the isolated intestinal mucosa. Biochem Pharmacol 26:99-108, 1977.

26. Vogt FB, Johnson PC: Plasma volume and extracellular-fluid volume changes associated with ten days recumbency. Aerospace Med 38:21-25, 1967.

27. Wagner JG: Fundamentals of clinical pharma- 
cokinetics. Hamilton, Ill., 1975, Drug Intelligence Publications.

28. Weiner IM: in Brodie BB, Gillette JR, editors: Handbook of experimental pharmacology. Berlin-Heidelberg-New York, 1971, SpringerVerlag, vol. 28, part I, p. 328.

29. Yeh KC, Kwan KC: A comparison of numerical integrating algorithms by trapezoidal, lagrange, and spline approximations. J Pharmacokinet Biopharm 6:79-98, 1978.

\section{Appendix}

Kinetic parameters were estimated as follows (see also references 5 and 18 ).

To estimate the area under the serum concentration-time curve (AUC), $\int_{0}^{\mathrm{T}} \mathrm{Cdt}$, up to the last sampling time, $\mathrm{T}$, in which there was a detectable concentration, the ordinary trapezoidal rule ${ }^{30}$ was used for oral data and the logarithmic trapezoidal rule $^{32}$ was used for intravenous data. To estimate the first moment, $\int_{0}^{\mathrm{T}} \mathrm{tCdt}$, following intravenous administration, the ordinary trapezoidal rule was used.

The method of least squares was applied to the natural logarithms of serum concentrations and the corresponding times to obtained $\lambda_{1}^{P_{0}}\left(\lambda_{1}^{P_{0}}\right.$ if oral data and $\lambda^{11}$ if intravenous data) using those concentration-time data (see Table II) which appeared to be $\log$ linear. The equation of the straight line is given below:

$$
\operatorname{lnC}=/ \mathrm{nI}-\lambda_{1} \mathrm{t}
$$

in which $\mathrm{C}$ is the serum concentration at time $\mathrm{t}, l \mathrm{nI}$ is the intercept on the ordinate axis, and $\lambda_{1}$ is the apparent first-order elimination rate constant. The lineestimated concentration, $\hat{\mathrm{C}}_{\mathrm{T}}$, at time $\mathrm{T}$ was obtained by substituting $\mathrm{T}$ for $\mathrm{t}$ in equation $\mathrm{I}$, then converting to equation 2 :

$$
\hat{\mathbf{C}}_{\mathrm{T}}=\mathrm{e}^{\left(l \mathrm{nI}-\lambda_{\mathrm{I}} \mathbf{T}\right)}
$$

Total areas were obtained with equation 3:

$$
\mathrm{AUC}=\int_{0}^{\infty} \mathrm{Cdt}=\int_{0}^{\mathrm{T}} \mathrm{Cdt}+\hat{\mathrm{C}}_{\mathrm{T}} / \lambda_{\mathrm{l}}
$$

The renal clearance was obtained as the ratio of the amount of drug excreted in the urine in $48 \mathrm{hr}$ to AUC from 0 to $48 \mathrm{hr}$.

Total body clearance was calculated with equation 4:

$$
\mathrm{Cl}_{\mathrm{B}}^{\mathrm{VV}}=\mathrm{D}_{\mathrm{IV}} /(\mathrm{AUC})_{\mathrm{IV}}
$$

The value of $f$ was obtained with equation 5 :

$$
\mathbf{f}=\mathrm{Cl}_{\mathrm{r}}^{\mathrm{IV}} / \mathrm{Cl}_{\mathrm{B}}^{\mathrm{IV}}
$$

The value of $F_{P^{n}}$ was obtained with equation 6 which, in turn, may be obtained from one of the equations of Kwan and Till. ${ }^{18}$

$$
\mathrm{F}_{\mathrm{P} 0}=\frac{\mathrm{D}_{\mathrm{lV}}(\mathrm{AUC})_{\mathrm{P}_{0}}}{\mathrm{D}_{\mathrm{P}^{0}}(\mathrm{AUC})_{\mathrm{IV}}}-\frac{\left[\mathrm{Cl}_{\mathrm{r}}^{\mathrm{V}}-\mathrm{Cl}_{\mathrm{r}}^{\mathrm{P}_{0}}\right](\mathrm{AUC})_{\mathrm{P}_{0}}}{\mathrm{D}_{\mathrm{P}_{0}}}
$$

Usually $F_{P_{0}}$ is estimated from just the first term on the right-hand side of equation 6 , but under those conditions renal clearance is assumed constant after intravenous and oral administration. However, the renal clearance of bretylium in our study did not remain constant and equation 6 compensates for this lack of constancy,

$V_{\text {dss }}$ was estimated directly from the serum concentration-time data with the equation of Benet and Galeazzi ${ }^{5}$ shown in our symbolism as equation 7 :

$$
\begin{aligned}
& \mathrm{V}_{\mathrm{dss}}=\frac{\mathrm{D}_{\mathrm{IV}} \int_{0}^{\infty} \mathrm{tCdt}}{\left[\int_{0}^{\infty} \mathrm{Cdt}\right]^{2}}= \\
& {\left[\mathrm{D}_{\mathrm{IV}} \quad \int_{0}^{\mathrm{T}} \mathrm{tCdt}+\frac{\hat{\mathrm{C}} \cdot \mathrm{T}}{\lambda_{1}}+\frac{\hat{\mathrm{C}}}{\lambda_{1}^{2}}\right]} \\
& {\left[\int_{0}^{\mathrm{T}} \mathrm{Cdt}+\frac{\hat{\mathrm{C}}_{\mathrm{T}}}{\lambda_{1}}\right]_{2}^{2}}
\end{aligned}
$$

